\title{
DISSEMINATED TUBERCULOSIS IN A PREGNANT WOMAN PRESENTING WITH NUMEROUS BRAIN TUBERCULOMAS
}

\section{Case report}

\author{
Emerson L. Gasparetto', Priscilla Tazoniero², Arnolfo de Carvalho Neto ${ }^{3}$
}

\begin{abstract}
Tuberculosis is an infectious disease caused by Mycobacterium tuberculosis, which has the pulmonary form as the most common presentation. Dissemination of the disease is common in immunocompromised patients, but immunodeficiency related to pregnancy severe enough to cause dissemination of the Mycobacteria is exceedingly rare. When dissemination occurs, any organ may be affected and in central nervous system, the infection presents as meningitis and single brain parenchyma tuberculomas. We report the case of a 17 year-old woman at the 34th week of pregnancy with respiratory and high intracranial pressure symptoms. On the day before admission she had a sudden onset of paraparesis and urinary retention and ten hours after the delivery she presented with paraplegia. The chest X-ray and CT scan were compatible with miliary tuberculosis. The cranial CT scan revealed numerous rounded hypodense lesions located at cerebral and cerebellar hemispheres, which presented ring-like enhancement after contrast injection. The patient underwent a craniotomy with biopsy of the lesions confirming the diagnosis of brain tuberculomas. The three-drug regimen was started and the cranial CT scan performed a year after diagnosis showed no brain lesions. We emphasize the aggressive dissemination of the disease in this case associated with pregnancy and the importance of early diagnosis and institution of therapy resulting in regression of the lesions.
\end{abstract}

KEY WORDS: central nervous system, tuberculosis, pregnancy, tuberculoma.

\begin{abstract}
Tuberculose disseminada em uma paciente grávida apresentando múltiplos tuberculomas cerebrais: relato de caso.

RESUMO - A tuberculose é doença infecciosa causada pelo Mycobacterium tuberculosis e tem na forma pulmonar a sua apresentação mais comum. A disseminação da doença é comum em pacientes imunodeprimidos. Entretanto, imunodeficiência relacionada à gravidez suficientemente severa para causar disseminação da micobactéria é rara. Quando a disseminação ocorre, qualquer órgão pode ser afetado e, quando ela se faz para o sistema nervoso central, apresenta-se mais comumente como meningite ou tuberculoma único. Relatamos o caso de uma paciente de 17 anos na $34^{\text {a }}$ semana de gestação com sintomas pulmonares e hipertensão intracraniana. No dia anterior ao internamento a paciente apresentou episódio súbito de paraparesia e retenção urinária. A paciente evoluiu para parto normal e dez horas após apresentou paraplegia. A radiografia simples e a tomografia de tórax foram compatíveis com tuderculose miliar. A tomografia de crânio mostrou múltiplas lesões hipodensas arredondadas nos hemisférios cerebrais e cerebelares, as quais apresentaram realce anelar após injeção de contraste. A paciente foi submetida à craniotomia com biópsia de uma das lesões, que confirmou o diagnóstico de tuberculoma. Iniciou-se tratamento com regime tríplice e a tomografia de crânio realizada um ano após o diagnóstico foi normal.
\end{abstract}

PALAVRAS-CHAVE: sistema nervoso central, tuberculose, gravidez, tuberculoma.

Tuberculosis is an infectious disease caused by Mycobacterium tuberculosis, which has high morbidity and mortality and represents a public health problem, especially in developing countries ${ }^{1,2}$. Its most common presentation is the pulmonary form, either by bronchogenic or hematogenic form. Extra-

Discipline of Diagnostic Radiology, Department of Internal Medicine. University of Parana School of Medicine, Curitiba PR, Brazil (UFPR). ${ }^{1}$ Resident of the Section of Diagnostic Radiology, (UFPR), ${ }^{2}$ Medical Student; ${ }^{3}$ Assistant Professor of the Discipline of Diagnostic Radiology.

Received 12 October 2002, received in final form 21 March 2003. Accepted 4 April 2003.

Dr. Emerson L. Gasparetto - Avenida Silva Jardim 296/502 - 80230-000 Curitiba PR - Brasil. FAX: 5541 323-4274. E-mail: gasparetto@hotmail.com 
pulmonary dissemination of tuberculosis is common in immunocompromised patients and the infection of the central nervous system may manifest as meningitis, abscess or tuberculoma formation ${ }^{3-6}$. Most commonly the intracranial infection presents itself as meningitis and when affects the brain parenchyma it does in the form of single lesions ${ }^{3,5-7}$. Aggressive dissemination of tuberculosis related to pregnancy is rarely reported in the literature.

We report present a patient with dissemination of tuberculosis during the end of the pregnancy, who presented with central nervous system symptoms and numerous brain tuberculomas, diagnosed by histological examination. We also emphasize the importance of the early institution of the medical treatment, which may result in complete regression of all the lesions as presented in this case.

\section{CASE}

A 17 year-old woman at the 34th week of pregnancy started few months earlier with fever, chills, night sweats, cough with purulent sputum and weight loss. A week before hospital admission the patient presented with headache, nausea and vomiting. Three days later she experienced a sudden onset of paraparesis and urinary retention. Two months before the pregnancy, she had a PPD skin test and a chest $\mathrm{x}$-ray, which were normal, as all the prenatal investigation. At the hospital, the patient developed paraplegia ten hours after delivery of a normal child. Physical examination showed paraplegia, absent deep tendon reflexes, central facial palsy, bilateral palsy of the $\mathrm{VI}$ and nucal rigidity. The chest $\mathrm{x}$-ray and CT scan reveled multiple micronodular lesions in the lung parenchyma, compatible with miliary tuberculosis (Fig 1). Spine CT scans were unremarkable. The cranial CT scan showed twentyeight rounded hypodense lesions located at cerebral and cerebellar hemispheres, measuring between 6 and $18 \mathrm{~mm}$ (average, $13 \mathrm{~mm}$ ), with marked surrounding edema and ring-like enhancement after contrast injection (Fig 2 and 3). The patient underwent a craniotomy with biopsy of the lesions. Histological examination revealed immature granulomatous inflammation, extensive caseous necrosis, Langhans giant cells, lymphocytic inflammation, and acidfast bacilli on Ziehl-Nielsen stain, confirming the diagnosis of the immature form of tuberculous granulomas (Fig 4). The therapeutic trial consisted of the three-drug regimen administered during 12 months (isoniazide and rifampicin for 12 months and ethambutol for three months). Followup cranial CT scan performed a year after diagnosis showed complete regression of all the lesions.

\section{DISCUSSION}

The formation of intracranial tuberculomas is an uncommon form of presentation of the infection by Mycobacterium tuberculosis, specially when numerous as in our case. Ravenscroft et al. ${ }^{5}$ studied 202 children with tuberculous meningitis and found intracranial granulomas in 34 (17\%). However, only four patients presented with multiple brain granulomas on admission. All the patients with these multiple tuberculomas had chest radiographs suggestive of miliary tuberculosis. They concluded that in the presence of a heavy bacillary load as in miliary tuberculosis, seeding to the central nervous system may

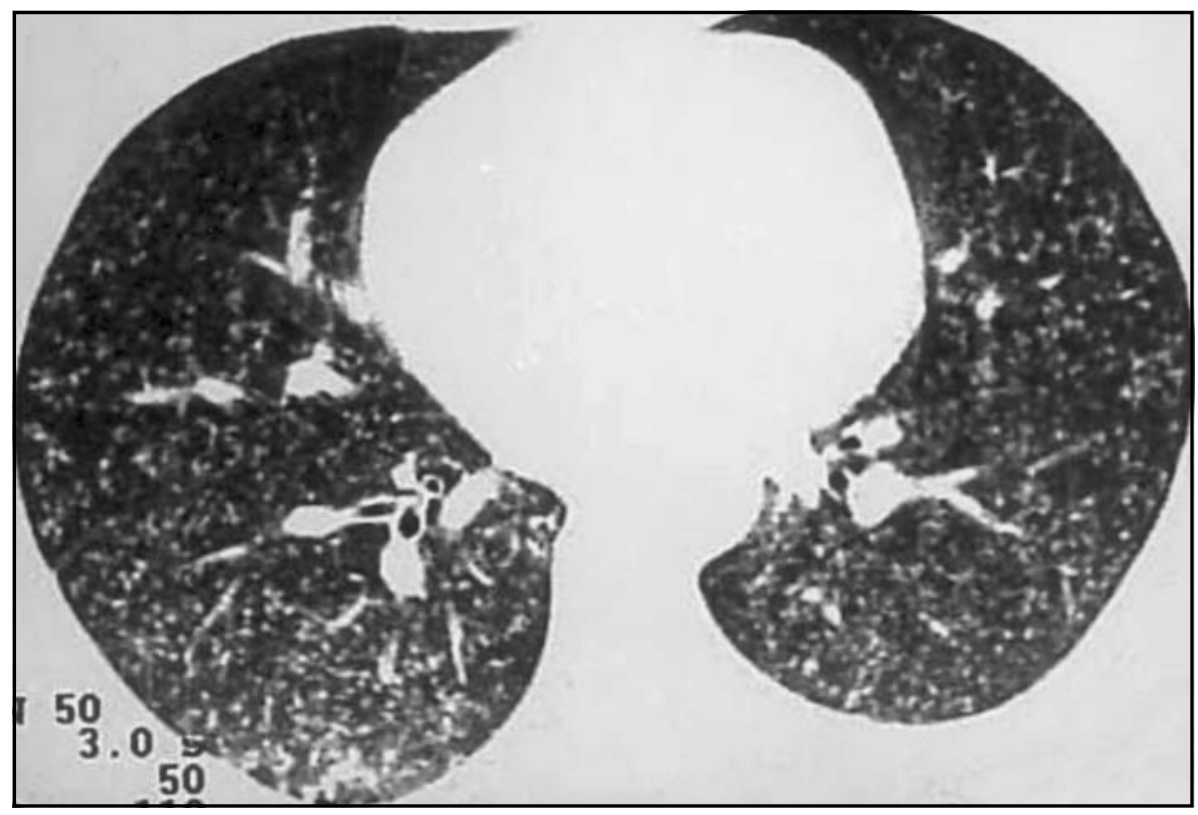

Fig 1. Chest CT scan revealing multiple micronodules at the lung parenchyma, compatible with miliary tuberculosis. 


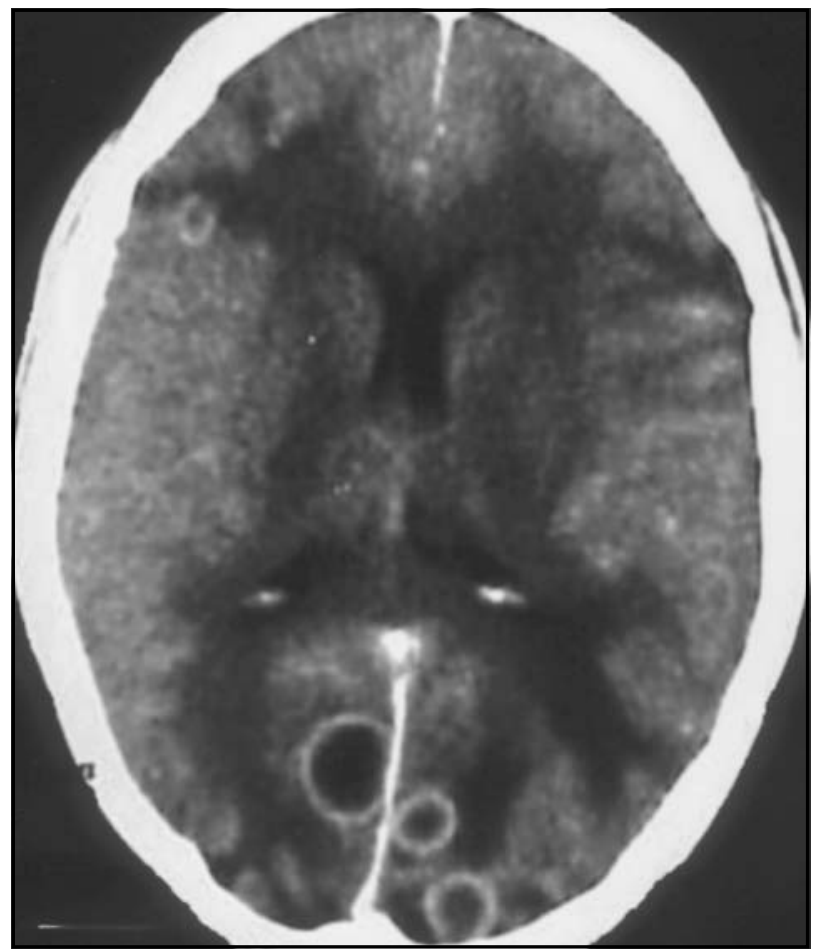

Fig 2. Cranial CT scan after contrast injection revealing multiple rounded hypodense lesions located at cerebral hemispheres, with marked surrounding edema and ring-like enhancement.

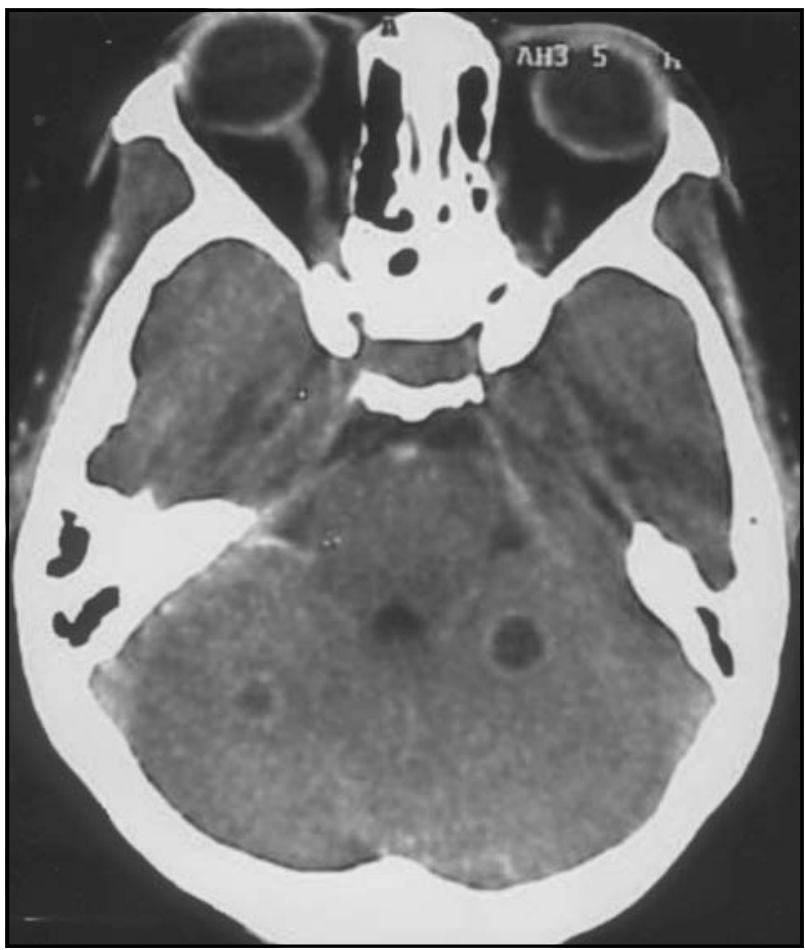

Fig 3. Cranial CT scan after contrast injection showing two rounded hypodense lesions located at cerebral hemispheres, with ringlike enhancement.

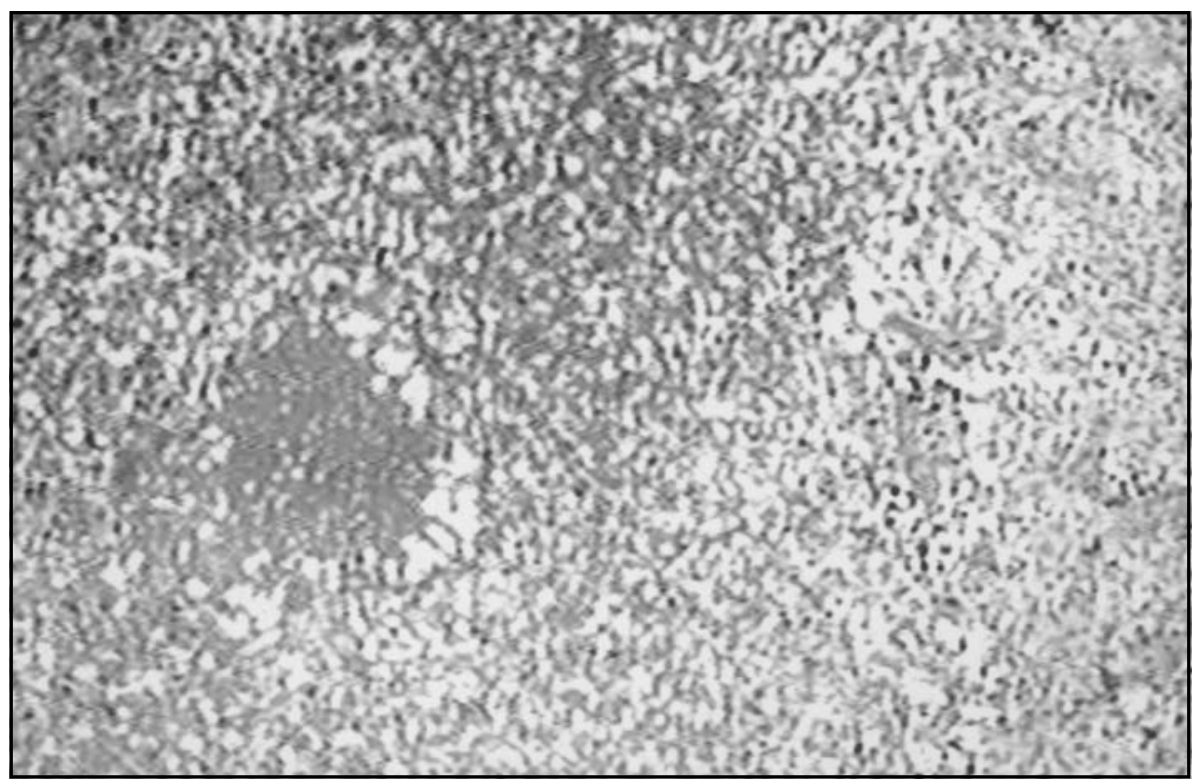

Fig 4. Photomicrography showing an immature granulomatous inflammation, with caseous necrosis, Langhans giant cells and lymphocitic inflammation (HE x 100).

result in multiple granulomas. Hematogeneous spread of tubercle bacilli is further supported by the vascular distribution of the lesions, particularly in the region of the middle cerebral artery. Studies in HIVinfected patients demonstrated that among those with parenchymal tuberculoma, $10 \%$ to $34 \%$ had mul- tiple lesions, therefore there is a direct relationship between the degree of immunossupression and the presence of multiple brain tuberculomas ${ }^{6}$.

Macroscopically, the brain tuberculomas are classified into mature and immature forms. The mature form consists of a well-defined avascular mass with 
central caseating necrosis, surrounded by firm collagenous capsule or granulation ${ }^{8,9}$. Immature tuberculomas are represented by multiple small tubercles, some with caseating or cystic centers dispersed within edematous brain. Some may be attached to the dura and others may calcify ${ }^{3}$. These immature forms, which were observed in our case, strongly suggest a marked degree of immunodeficiency.

Numerous authors have described the multiple features of tuberculomas on CT and MRI. The most frequent patterns on CT scans are small isodense or slightly hyperdense nodules with peripheral edema, showing homogeneous or ringlike enhancement after contrast . Larger ring-enhancing lesions or lobulated masses may be found, representing maturer forms $s^{3-6,9-11}$. The "target sign" has been described as characteristic of tuberculomas, consisting of a ringenhancing lesion with an additional central area of enhancement or calcification ${ }^{3-6,9-11}$. MR images may not distinguish tuberculomas from surrounding brain and edema on T1- and T2-weighted images. Sometimes a hypointense ring may separate the hyperintense center from the peripheral edema on T2weighted images. With gadolinium injection, T1weighted images often show ring-enhancing lesions ${ }^{2,9,12}$. In our patient, cranial CT scan revealed numerous rounded hypodense lesions with surrounding edema and ring-enhancing pattern, mainly located at cerebral and cerebellar hemispheres.

Del Brutto and Mosquera ${ }^{11}$ concluded that the imaging findings of intracranial tuberculomas are nonspecific, and they have to be differentiated from other causes of space-occupying lesions such as malignant gliomas, pyogenic abscess, toxoplasmosis, cysticercosis, lymphoma, and syphilitic gummas s, $10,11^{2}$ The use of more recent imaging tools such as MRI spectroscopy and diffusion may be helpful in defining the correct diagnosis and also in avoiding the need for invasive procedures. Capon et al..$^{13}$ reported a similar case of a woman in her seventh month of pregnancy, who presented with headache, papilledema, gait ataxia, nucal rigidity, flaccidity of the four limbs and impairment of consciousness. The patient underwent surgical exploration of the posterior fossa, which showed mild herniation of the tonsils and swollen cerebellar hemispheres. Biopsies were inconclusive. At autopsy the leptomeninges were thickened. Coronal sections demonstrated ten nodular lesions randomly distributed in both brain hemispheres. Histological findings of these lesions consisted of confluent tubercles, forming large tuberculomas mainly located in the cortical region. They were composed of lymphocytes, plasma cells and Langhans cells, and on Ziehl-Nielsen stain acidfast bacilli were oberserved.

The immunossupression related to pregnancy can lead to infectious diseases, whose clinical and imaging presentation may resemble the same diseases that occur in highly immunocompromised patients ${ }^{14-16}$. The formation of intracranial tuberculomas is an uncommon finding in the course of tuberculosis and when observed, there is usually a single lesion. Multiple tuberculomas located at the brain parenchyma are even less common but should not be disregarded at the moment of the differential diagnosis of space-occupying lesions, especially in patients whose immune system is compromised and at those who are from endemic areas and/or have films of other organ systems suggesting miliary tuberculosis.

\section{REFERENCES}

1. Nunes C, Cunha S, Gomes I, et al. Fatores prognósticos de letalidade na meningoencefalite tuberculosa. Arq Neuropsiquiatr.1998;58:772-777.

2. Nunes C, Gomes I, Tavares A, Melo A. Clinical and laboratory characteristics of 62 tuberculous meningoencephalites cases. Arq Neuropsiquiatr 1996;54:222-226.

3. Campi de Castro C, Hesselink JR. Tuberculosis. Neuroimaging Clin N Am 1991;1:119-139.

4. Magalhães ACA, Bacheschi LA. Viral and nonviral infections of the nervous system. In: Greenberg JO, Raymond AD (eds). Neuroimaging. New York McGraw-Hill, 1995:385-412.

5. Ravenscroft A, Schoeman JF, Donald PR. Tuberculous granulomas in childhood tuberculous meningitis: radiological features and course. J Trop Pediatr 2001;47:5-12.

6. Whiteman MLH. Neuroimaging of central nervous system tuberculosis in HIV-infected patients. Neuroimaging Clin N Am 1997;7:199-214.

7. Rebai R, Boudawara MZ, Bahloul K, et al. Cavernous sinus tuberculoma: diagnostic difficulties in a personal case. Surg Neurol 2001;55:372-375.

8. Kobzik L. The lung. In: Cotran RS, Kumar v, Collins T (eds). Robbins pathologic basis of disease 6.Ed. Philadelphia: WB Saunders,1999:697-755.

9. Lee WY, Pang KY, Wong CK. Brain tuberculoma in Hong Kong. HKMJ 2002;8:52-56.

10. Thonnell L, PendleS, Sacks L. Clinical and radiological features of South African patients with tuberculomas of the brain. Clin Infec Dis 2000;31:619-620.

11. Del Brutto O, Mosquera A . Brainstem tuberculoma mimicking glioma: the role of antituberculous drugs as a diagnostic tool. Neurology 1999;52:210-211.

12. Gupta RK, Vatsal DK, Husain N, et al. Differentiation of tuberculous from pyogenic brain abscesses with in vivo proton MR spectroscopy and magnetization transfer MR imaging. Am J Neuroradiol 2001;22:1503-509.

13. Capon A, Noterman J, Hubert JP, Klastersky J, Flament-Durand J. Multiple tuberculomas of the brain: report of a case. Acta Neurochir (Wien) 1975;32:303-312.

14. Pearson H. Reproductive Immunology. Immunity's pregnant pause. Nature. 2002;420:265-266.

15. Rich KC, Siegel JN, Jennings C, Rydman RJ, Landay AL. CD4+ lymphocytes human immunodeficiency virus (HIV) infection: evidence for pregnancy-induced depression in uninfected and HIV-infected women. J Infect Dis 1995;172:111-117.

16. Covelli HD, Wilson RT. Immunologic and medical considerations in tuberculin-sensitized pregnant patients. Am J Obstet Gynecol 1978;132:256-259. 